\title{
PW03-024 - A transgenic mouse model for variant procaspase-1
}

\author{
A Hermsdorf ${ }^{\text {* }}$, F Pessler ${ }^{2}$, H Luksch', S Winkler ${ }^{1}$, R Naumann ${ }^{3}$, J Roesler ${ }^{1}$, A Roers ${ }^{4}$, A Rösen-Wolff \\ From 7th Congress of International Society of Systemic Auto-Inflammatory Diseases (ISSAID) \\ Lausanne, Switerland. 22-26 May 2013
}

\section{Introduction}

We have detected several genetic variants of CASP1 in patients suffering from unexplained recurrent febrile episodes. Paradoxically, in vitro and in vivo analyses of patients' cells revealed decreased enzymatic activity of these caspase- 1 variants leading to impaired cytokine production despite the proinflammatory phenotype of the patients. The pathophysiological processes associated with CASP1 variants are still under investigation.

\section{Objectives}

In order to recapitulate the effects of the CASP1 mutations found in the patients we tried to establish a bacterial artificial chromosome (BAC) transgenic mouse line expressing enzymatically inactive Casp1 ${ }^{\text {C284A }}$ under the control of the own promoter.

\section{Methods}

The purified BAC fragment containing Flag-tagged

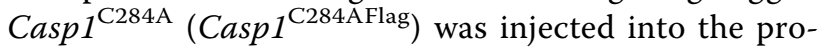
nuclei of fertilized C57Bl6 mouse oocytes, followed by transfer of these oocytes to pseudopregnant foster mothers. Pups born from these mothers were analyzed for the presence of full-length Casp1 ${ }^{\text {C284AFlag }}$ by screening with sequence specific PCR, Southern blot, and sequencing of the transgene. Casp1 ${ }^{\mathrm{C} 284 \mathrm{AFlag}}$ transgenic mice were crossed to conventional Casp1 knock-out (KO) mice and the immunological phenotype of the progeny was analyzed by in vitro stimulation of BMDCs. Expression levels of the $\operatorname{Casp1}^{\mathrm{C} 284 \mathrm{AFlag}}$ transgene were quantified by qRT-PCR and Western blots. Released cytokine levels were determined by cytometric bead arrays.

'Department of Pediatrics, University Clinic Carl Gustav Carus, TU Dresden, Dresden, Germany

Full list of author information is available at the end of the article

\section{Results}

From two independent pronucleus injections we received 180 pups. Only three of them harbored transgene sequences and only one female animal proved to harbor the complete Casp ${ }^{\text {C284AFlag }}$ transgene (TG). Crossing to Casp1 KO mice yielded the following genotypes: Casp1WT/WT/TG, Casp1WT/KO/TG, and Casp1KO/ $\mathrm{KO} / \mathrm{TG}$. qRT-PCR analyses revealed that unstimulated Casp1 ${ }^{\text {C284AFlag }}$ transcription was reduced to $0.1 \%$ of wildtype Casp1. Hence, protein expression could not be detected in unstimulated cells. However, stimulation with LPS upregulated transcription and low-level translation of Casp1 $1^{\text {C284AFlag }}$ in BMDCs. Determination of released cytokines after LPS/ATP stimulation revealed increased release of IL-6 and TNF-a from Casp1WT/KO/TG mice with proven Casp1 ${ }^{\text {C284AFlag }}$ expression.

\section{Conclusion}

These data indicate that even tiny amounts of Casp1 $1^{\text {C284A- }}$ Flag induced release of other proinflammatory cytokines and that this might contribute to the proinflammatory phenotype observed in our patients. Baseline expression of enzymatically inactive Casp ${ }^{\text {C284AFlag }}$ may be embryonically lethal in mice since not a single mouse could be generated which expressed the transgene under unstimulated conditions. Hence, a conditional Casp1 $1^{\text {C284AFlag }}$ knock-in mouse model is being established.

This study was supported by the Federal Ministry of Education and Research (BMBF; Deutsches Netzwerk für Primäre Immundefekte PID-NET) and by EU Marie Curie International Reintegration grant no. GA-2007224894 (F.P.).

\section{Disclosure of interest}

None declared. 


\section{Authors' details}

'Department of Pediatrics, University Clinic Carl Gustav Carus, TU Dresden, Dresden, Germany. ${ }^{2}$ TWINCORE Center for Clinical and Experimental Infection Research, Hannover, Germany. ${ }^{3}$ Max Planck Institute of Molecular Cell Biology and Genetics, Germany. ${ }^{4}$ Insitute of Immunology, TU Dresden, Dresden, Germany.

Published: 8 November 2013

doi:10.1186/1546-0096-11-S1-A250

Cite this article as: Hermsdorf et al:: PW03-024 - A transgenic mouse model for variant procaspase-1. Pediatric Rheumatology 2013 11(Suppl 1): A250.

Submit your next manuscript to BioMed Central and take full advantage of:

- Convenient online submission

- Thorough peer review

- No space constraints or color figure charges

- Immediate publication on acceptance

- Inclusion in PubMed, CAS, Scopus and Google Scholar

- Research which is freely available for redistribution

Submit your manuscript at www.biomedcentral.com/submit
Ciomed Central 